\title{
PURSUING THE RIGHT FOR TODAY, SECURING THE ENVIRONMENT FOR TOMORROW
}

\author{
Salma Yusuf ${ }^{1}$ \\ University of London
}

\begin{abstract}
:
The article is set within the context of the emerging discourse on environmental security and sustainable development. It seeks to inject a new paradigm into the discourse by demonstrating how a human rights based approach could aid the advancement of the agenda of environmental security and protection, while at the same time generating impetus for international human rights law to widen its purview of focus, through a comprehensive examination of the jurisprudence of the European Court of Human Rights. The article culminates in an analysis of the raison d'être for the formal establishment of a human right to an environment in international law, and the challenges of such a project, if undertaken.
\end{abstract}

Keywords: Environment, Human Rights, International Law, European Court of Human Rights.

\section{Resumen:}

El artículo se enmarca en el contexto del discurso emergente sobre seguridad medioambiental y desarrollo sostenible. Trata de introducir un nuevo paradigma en el discurso intentando demostrar la forma como una aproximación basada en los derechos humanos podría ayudar en el avance de la agenda de seguridad y protección ambiental, generando al mismo tiempo un impulso en el desarrollo del derecho internacional de derechos humanos, ampliando su ámbito de atención, a través de un examen exhaustivo de la jurisprudencia del Tribunal Europeo de Derechos Humanos. El artículo finaliza con un análisis de los fundamentos para el establecimiento formal de un derecho humano del medioambiente en el derecho internacional y los desafios de este proyecto, si se llegara a realizar.

Palabras clave: Medio ambiente, Derechos Humanos, Derecho Internacional, Tribunal Europeo de Derechos Humanos.

Copyright (C) UNISCI, 2012.

Las opiniones expresadas en estos artículos son propias de sus autores, y no reflejan necesariamente la opinión de UNISCI. The views expressed in these articles are those of the authors, and do not necessarily reflect the views of UNISCI.

\footnotetext{
${ }^{1}$ LL.B, University of London; LL.M, Queen Mary, University of London; Queen Mary Scholar 08- 09; Lecturer, Masters in Human Rights and Democratization, University of Colombo and University of Sydney; Lecturer, Bachelor of Laws, University of Northumbria - Regional Campus for Sri Lanka \& Maldives.

E-mail: salmayusuf@gmail.com.
} 


\section{Introduction}

The article is set within the context of the emerging discourse on environmental security and sustainable development. It seeks to inject a new paradigm into the discourse by demonstrating how a human rights based approach could aid the advancement of the agenda of environmental security and protection, while at the same time generating the impetus for international human rights law to widen its purview of focus. It establishes how a platform that views human rights and environmental protection as inextricably linked can be mutually reinforcing, through a comprehensive examination of the jurisprudence of the European Court of Human Rights (ECTHR). The purpose of such an endeavour is two-fold. Firstly, to establish the positioning of the European Court of Human Rights in relation to the issue of human rights and environment. Secondly, it assesses the contribution that the ECTHR has made to the subject.

The paper begins by describing the relationship between human rights and international environmental law through the consideration of various sources of international law in general and environmental law in particular. The paper moves on to discuss if there does in fact exist a human right to an environment, and if so, what it should entail. It then analyzes the raison d'être for the formal establishment of such a human right in international law, and the challenges of such a project, if undertaken.

There is little disagreement that human rights and environmental protection share a filial relationship. In the words of the international scholar, Dinah Shelton, 'The interrelationship between human rights and environmental protection is undeniable.' Similarly, equally little disagreement exists on the distinct and separateness of the two areas as argued by commentators such as John G. Merrills who declare that 'International environmental law and the law of human rights embody distinct but related concerns for the modern world.'

This interrelationship was explored as early as 1972 at the Stockholm Conference on the Human Environment. Resource depletion fit within this agenda and stimulated interest among developing states which culminated in a Declaration recognizing environmental protection as a precondition for the enjoyment of several human rights. Subsequently, at the United Nations Conference on the Human Environment, Principle 1 of the Final Declaration states the 'Man has the fundamental right to freedom, equality and adequate conditions of life in an environment of a quality that permits a life of dignity and well-being, and he bears a solemn responsibility to protect and improve the environment for present and future generations.' Thereafter, the 1968 United Nations Tehran Conference on Human Rights declared that all human rights are 'interdependent and indivisible', hence opening the door for consideration of complex issues like environmental rights. Twenty years after the Stockholm Conference, it is remarkable that the United Nations General Assembly recalled the language of the Stockholm Declaration in its Resolution 45/94.

The landmark international instrument that addresses sustainable development of the environment after the Stockholm Declaration is the Rio Declaration of 1992.

It must be noted that the Rio Declaration seems to consciously avoid reference to environmental rights although it does speak of 'national rights' to exploit the environment and the 'right to develop.' It may be argued that in other areas of international law there is a gradual coming together of various 'strands,' including sustainable development and human rights, indicating the extent to which rights within generations are seen as indivisible from the pursuit of sustainability. For example, Article 4 of the 1995 Draft International Covenant on 
Environment and Development of the International Union for Conservation of Nature (IUCN) provides that 'peace, development and environmental protection and respect for human rights and fundamental freedoms are interdependent.' Several constitutions and even the Ksentini Report by the UN Special Rapporteur on Human Rights and the Environment identifies various substantive rights and freedoms such as freedom from pollution and environmental degradation, and the right to the highest attainable standard of health free from environmental harm, qualified by exceptions similar to those found in the European Convention on Human Rights.

However, whether these are anything more than policy aspirations or symbolic gestures is questionable. It has been opined by commentators, that while they may guide decisionmakers in a general sense, courts are reluctant to require potentially vast sums of money to be spent on environmental improvement works to uphold such rights, not least because this might involve protecting the 'first right to get to court' at the expense of others, perhaps more worthy of improvement schemes.

\section{Human Rights and Environment Security - The Essential Relationship}

The question that immediately arises then is, how would emphasizing international human rights law contribute to environmental security and protection? The substantial practical reason would be that it currently provides the only set of international legal procedures that can be invoked by those whose well-being suffers due to environmental degradation, to seek redress for harm that is the consequence of an act or omission attributable to a State.

Further, the inclusion of inaction is significant because most environmental harm is due to non-state activity. Thus, while no international human rights procedure allows a direct action against private enterprises or individuals who cause environmental harm, a State allowing such harm may be held accountable.

There have been identified four principal and complementary approaches to characterize the relationship between human rights and the environment. Firstly, incorporating and utilizing those human rights guarantees deemed necessary or important to ensuring effective environmental protection - this approach emphasizes procedural rights such as freedom of association which permits the existence and activities of Non-Governmental Organizations, and their right of access to information concerning potential threats to the environment.

While such an approach is commendable, writers like Johanna Rinceanu argue that though the potential for improving environmental protection through effective guarantees of procedural rights is solid, the absence of complaint mechanisms or other recourse in international agreements is a limiting aspect.

Secondly, human rights law re-casts or interprets internationally guaranteed human rights to include an environmental dimension when environmental degradation prevents full enjoyment of the guaranteed rights, as seen in Judge Weeramantry's opinion in 1997 of the Gabcikovo-Nagymaros Project, Hung v Slovk. The primary advantage of the second approach over the first is that existing human rights compliant procedures may be employed against those states whose level of environmental protection falls below that necessary to maintain any of the guaranteed human rights. Using existing human right law has its limits, however, 
because it cannot easily resolve threats to other species or to ecological processes, if these are not linked to human well-being.

The third approach to define the relationship between human rights and the environment would be the formulation of a new human right to an environment that is not defined in purely anthropocentric terms namely, an environment that is not only safe for humans but one that is ecologically- balanced and sustainable in the long term.

Finally, the fourth approach would be one that prefers to address environmental protection as a matter of human responsibilities rather than rights, for instance, as seen in the recent United Nations Earth Charter of March 2000.

Those arguing for this approach contend that ecological rights can balance human rights by introducing ecological limitation on human rights. As writer Prudence Taylor observes, 'The objective of these limitations is to implement an eco-centric ethic in a manner which imposes responsibilities and duties upon human kind to take intrinsic values and the interests of the natural community into account when exercising its human rights.'

This sentiment is reinforced by writers such as Catherine Redgwell who observe that 'there has been an increasing recognition in international environmental law of the intrinsic value of animals and nature which goes beyond merely an incidental spill-over effect.'

\section{Human Rights and Environment Security - A View from the European Court of Human Rights}

Interestingly, from Stockholm to the present, most advances in developing environmental rights have occurred, first and almost exclusively, at the regional level. The European Union, through its jurisprudence developed by the European Court of Human Rights (ECTHR), has been at the forefront of regional contributions to environmental security and protection via a human rights based approach. The following discussion examines the work of the ECTHR, and the tools and frameworks used to advance the protection of the environment through human rights. The examination considers the wide and varied human rights through which the ECTHR seeks to achieve environmental security and protection.

Broadly, European human rights law operates at three levels in relation to the environment. At a general level, it accords significant symbolic weight to the idea of human rights. For the majority of people, human rights will tend to outweigh environmental rights or interests. The ECTHR has interpreted certain civil and political rights to protect against environmental harm. Thirdly, human rights law may have a more indirect impact in the environmental sphere.

For example, the European Convention on Human Rights (ECHR) provides for qualified freedoms like the freedom of expression (Article 10) and the right to assemble peacefully (Article 11). For instance, changes to environmental law or policy when argued through political protest rather than lobbying human rights law may justify such protest, or conversely, may restrict it by the use of one of the exceptions on which the Convention allows governments to rely. 
Since the ECHR protects civil and political freedoms it is not strong on protection for other interests like collective rights relating to environmental quality or resources. One reason for this is the involvement of questions of public interest and complex balancing of various, and sometimes even conflicting, interests. Moreover, as with European law, a rights-based approach to environmental law has been shunned in the the European Community Treaty in favour of integrating environmental protection into other policy sectors and reference to 'protecting the quality of the environment.' However, it must be remembered that though the European Court of Justice (ECJ) sometimes speaks the language of 'rights,' what is actually at stake is compliance by the Member States with specific legal obligation.

Regionally, the European Community generally guarantees the right of the individual to be informed about the environmental compatibility of products, manufacturing processes and their effects on the environment and industrial installations, and two general directives address rights of information.In the case of Leander $v$ Sweden, the applicant alleged violation of Article 10 of ECHR after he was refused access to a file that was used to deny him employment. The court unanimously dismissed the claim stating that "

The right of freedom to receive information basically prohibits a Government from restricting a person from receiving information that others wish or may be willing to impart to him. Article 10 does not...confer on the individual a right of access to a register containing information on his personal position, nor does it embody an obligation on the Government to impart such information to the individual.' Thus, it appears that this restrictive approach by the ECTHR construes 'right' narrowly by finding the Government liable only if it obstructs or hinders a person from receiving information. It does not seem to require a proactively responsible role for the Government in providing information to its citizens.

The ECTHR has applied its restrictive approach to environmental cases. The approach of the ECTHR can be contrasted with the views of the former Commission which adopted a broader approach including the right of the individual to receive information not generally accessible and that is of particular importance to him/her. In Guerra v Italy, the European Commission on Human Rights (ECOMHR) admitted the complaint insofar as there was a violation of a right to information but did not accept the claim of pollution damage.

The ECOMHR concluded that Article 10 imposes on States an obligation not only to disclose to the public available information on the environment but also the positive duty to collect, collate and disseminate information which would not otherwise be directly accessible to the public or brought to the public's attention. It acknowledged a fundamental right to information, at least in Europe, concerning activities that are dangerous for the environment or human well-being.

However, in 1998, the ECTHR reversed the expanded reading of Article 10 by ECOMHR and reaffirmed its earlier position, but unanimously found a violation of Article 8. It is noteworthy that the ECTHR adopted a more liberal approach to cases concerning freedom of press where the court held that the State may not extend defamation laws to restrict dissemination of environmental information of public interest. In Bladet Troms $\mathrm{V}$ Norway, the court justified its position stating that a decision otherwise would undermine the press' public watchdog role. The court went further in the case of Thoma $v$ Luxembourg saying that when criticizing public officials, as opposed to private individuals, a degree of exaggeration or even provocation is allowed when it is first, proportionate to the legitimate aim pursued; second, with sufficient reason provided for its necessity to the functioning of a democratic society; and third, is in the general interest. 
It might be argued, however, that this recourse to provocation and exaggeration given to journalists can be dangerous as the press is known for its tendencies of sensationalism. Thus, this approach is likely to create a 'slippery slope' when it comes to violating the protection of rights and reputation of public officials.

It might be argued that the approach of 'naming and shaming' should be allowed by the press only insofar as it reveals its sources of information and is based on pure facts alone. There should be no leeway for exaggeration. Despite its contribution to environmental protection, it is arguable that such a 'lax' approach- which should be distinguished from a 'relaxed' approach - is not likely to achieve anything more than an approach sans exaggeration and sensationalism. On the contrary, it is in all likelihood, that such a situation would turn out to be counter-productive where the public perception of the media will be one that is lacking is credibility as it is not operating based on pure facts.

Article 6 of the ECHR guarantees a fair and public hearing before a tribunal for the determination of rights and duties. In Oerlemans v Netherlands, Article 6 was deemed to apply to a case where a Dutch citizen could not challenge a ministerial order designating his land as a protected site. Similarly, the applicability of Article 6 was upheld in Zander v Sweden. Further, the right to remedy was held to extend to compensation for pollution under Article 6 in Zimmermann v Switzerland where the ECTHR found Article 6 applicable to a complaint about the length of the proceedings for compensation for injury caused by noise and air pollution from a nearby airport.

In a significant judgment the ECTHR held Turkey responsible for death caused by methane explosion under a negligence standard possibly rising to the level of gross negligence, where despite orders to local authorities by the Environmental Office that were informed by experts' reports, no action was taken.

Though the applicants won administrative judgment, compensation was never paid. However, the ECTHR reiterated that the right to life provision of the Convention contains not only a negative obligation to refrain from the use of force by state agents but also that an expansive interpretation of the right to life imposes positive obligations on states to take steps to safeguard the lives of those within their jurisdiction.

Further, it said that the obligation applies to any activity, public or not. Moreover, the court identified several factors for evaluating the circumstances of the case. The court included the public's right to information among the preventive measures that the state must take to protect the right to life.

The court went further to find Turkey in violation of its duties in the aftermath of the explosion under Article 2. The court went even further to indicate that prosecution may be necessary and that national courts should not allow life-endangering offenses to go unpunished in view of the deterrent function of the criminal law. Similarly, the court found that the government had violated the applicant's right to property contained in Article 1 of Protocol No 1 of the ECHR. Finally, the court found a violation of the right to a remedy contained in Article 13. The court awarded pecuniary and non-pecuniary damages.

In the case of Pialopoulos v Greece, ECTHR accepted the impugned measures aimed at environmental protection and thus served a legitimate state interest. However, it went on to hold that the applicants were entitled to compensation and that without it their property rights had been violated. 
Arguably, such an approach by the ECTHR may be termed a 'halfway' or 'compromised' approach since it does not entirely dismiss the individual's right but duly compensates him, without which it would be considered a violation. On the other hand, it might be argued with equal vigour that it is not a true compromise since preference has been accorded to state interest and compensation to the individual is merely a 'consolation prize.'

The European Commission on Human Rights and the ECTHR have held that environmental harm attributable to state action or inaction which has significant injurious effect on a person's home or private and family life is a breach of Article 8(1). However, Article 8(2) provides an exclusion clause for situations where harm may be excused, if it results from an authourized activity of economic benefit to the community in general, as long as there is no disproportionate burden on any particular individual.

States enjoy a margin of appreciation in determining the legitimacy of the aim pursued. Recent decisions of the court have shown to balance the competing interests of the individual and the community with deference to the state's decision. In Arrondelle v UK and Baggs v UK, the cases were admissible but resolved by friendly settlement which left unresolved numerous issues which were addressed in Powell v UK. In this case the ECTHR found that aircraft noise from Heathrow airport constituted a violation of Article 8 but was justified under Article 8(2). Noise was deemed acceptable under the principle of proportionality, a test that could be met if the individual had, as the ECTHR stated, 'the possibility of moving elsewhere without substantial difficulties and losses.'

It is arguable that in this case environmental protection was not high on the agenda of priorities for the ECTHR. The harm to the individual is weighted against the benefits to the community and it might be argued that since noise is not 'harmful' or 'dangerous' to the individual's life this decision by the ECTHR is justified. However, as far as environmental protection is concerned the same cannot be said.

In Hatton v UK, though the initial chamber found that the noise from increased flights between $4 \mathrm{am}$ and $6 \mathrm{am}$ violated the applicant's rights for their home and family life, it was overturned by a Grand Chamber decision. The Grand Chamber held that the state cannot simply refer to the economic well-being of the country 'in the particularly sensitive field of environmental protection' and required states to find alternative solutions.

The Grand Chamber held this to be a new and inappropriate test that failed to respect the subsidiary role of the court and the wide margin of appreciation afforded to the state. It went on to say that for a case to be successful, the individual must seriously and directly be affected by noise or other pollution. The court decided that the states should take into consideration environmental protection in acting within their margin of appreciation and said that the ECTHR should review this, but that in doing so should not accord a 'special status of environmental human rights.' Thus it was held that there was no violation of Article 8. This decision reflects the ECTHR hesitation in adopting an activist approach in general and with regards to environmental protection in particular.

It makes an outright rejection of a according special status for environmental human rights while not dismissing it completely as a criteria for judging state action. Thus, it may be concluded that the ECTHR is far from granting environmental rights a 'special place' as a 'new' human right but seems to prefer embracing it only as a factor in a larger decisionmaking process. Hence, it is arguable that such cases reveal that ECTHR is not a guardian for environmental rights protection but reflects a lesser degree of interest in environmental 
protection. An accurate description of the ECTHR position is perhaps one that is sensitive or sensitized to the issue but not one that is pro-actively supportive of according environmental rights a status of a separate human right.

In the aftermath of the Hatton judgment, other cases on noise pollution have had mixed success. In Ashworth v UK - the court held the application to be admissible.

In contrast, Gomez v Spain succeeded in its claim as the court held that noise levels were such that failure of the City Council to enforce its own noise abatement measures was seen as flouting local laws. Lopez Ostra v Spain was a major decision of the court where pollution was held to be a breach of Article 8 . First, the court did not require the applicant to exhaust administrative remedies to make this challenge but only to complete remedies applicable to enforcement of basic rights. The ECTHR went so far to hold that severe environmental pollution may affect individual's well-being and prevent them from enjoying their homes in to such an extent that their private and family life are affected but with no endangering to health. In this case, it found that the court had exceeded its margin of appreciation. In Guerra $\mathrm{v}$ Italy, the court reaffirmed that Article 8 imposed positive obligations on states to ensure respect for private or family life. However, the decision is strained due to reluctance in extending Article 10 on freedom of information to impose positive obligations on the state.

In Fadeyeva v Russia, the state was found to be in breach of Article 8 as there was no evidence that the state drafted or applied effective measures which took into account the interests of the local population and which would have been capable of reducing the pollution to acceptable levels which in turn would have prevented the deterioration of the applicant's health. Following the decision in Fadeyeva v Russia, the ECTHR found Russia to be in violation of Article 8 in the case of Ledyayeva, Zolotareva and Romashina v Russia (2006), despite difficulty in quantifying the exact effect on each individual's health and influence of other factors like vocation and age.

However, there was no doubt that it affected public health in general and the government had not put forward any new fact or argument capable of persuading the ECTHR to reach a different conclusion to Fayedeva.

Similarly, in the case of Giacomelli v Italy (2006) the ECTHR upheld a violation of Article 8 on the grounds that the state did not strike a fair balance between the interest of the community in having a plant for the treatment of toxic industrial waste, and the applicant's effective enjoyment of her rights under Article 8 - persistent noise and harmful emissions from the plant which was only 30 meters away from her house. The plant was built on agricultural land which eroded the soil and posed risk of contamination of ground water.

In the more recent case of Lars and Astrid Fagerskiold v Sweden (2008), the applicants complained violation of Article 8 and Article 1 of Protocol No 1 of the Convention on the basis of disturbing noise from wind turbines and light reflection from its rotor blades. They had bought their property for recreational purposes which had been hindered decreasing the value of their property. Additionally, no noise investigation had been carried out despite repeated requests. The court observed that the level of severity required to form an Article 8 violation in relation to environmental issues had not been attained. The court recalled that there exists no explicit right in the ECHR to a clean and quiet environment. It is illustrative from the case law of the ECTHR that an expansive interpretation of the notions of 'private life' and of 'home' has been adopted in its judgments - Niemietz v Germany and Demades v 
Turkey. The court found that noise level recommended by the World Health Organization was only slightly exceeding the recommended maximum level in Sweden. Thus the ECTHR found that the noise levels and light reflection in the present case were not so serious as to reach the threshold established in cases dealing with environmental issues.

In relation to complaint under Article 1 of Protocol No 1, operating the wind turbine is in the general interest as it is an environmentally-friendly source of energy which contributes to the sustainable development of natural resources. Alleged interference was proportionate to aims proved, and thus there was found to be no breach in the instant case. Additionally, the applicants had not submitted evidence to show reduction in property value and had not exhausted domestic remedies.

This case is particularly interesting as it demonstrates a conflict between two competing environmental interests - the environmental interest of the community on the one hand and the environmental interest of the individual on the other. This case, not unlike the others discussed above, is arguably reflective of a trend where the ECTHR, while being cognizant of the individual's rights to an environment, seems to tilt in favour of the states' and community interest in the matter.

Further, the ECTHR has made it explicitly clear that it does not advocate a separate human right to the environment while at the same time does not dismiss it as un-important in the assessment and balancing of competing interests when deliberating on the facts of a case before it.

Some might argue that this trend is reflective of according indirect protection to a right to the environment similar to the approach the ECTHR adopts when dealing with economic, social and cultural rights, where it is seen to make consideration for these rights under the guise of enforcing civil and political rights.

That said, it is safe to say that the ECTHR is sensitized to environmental concerns in making decisions and even though it has not reached the place of accepting it as a substantive and separate human rights, it is undoubtedly moving in a direction, where if it continues along the similar trajectory, the jurisprudence is likely to eventually crystallize into a situation where a human right to an environment becomes a norm.

For the time being, however, the ECTHR can be seen to be contributing to environmental protection of individuals, albeit in an indirect manner, with no special status being accorded, but rather as a 'factor' or 'criterion' in the judges' decision-making 'tool box.'

This article began by describing the relationship between human rights and international environmental law as related but distinct. As the preceding discussion illustrates, it is arguable that another way of describing the relationship is as one of mutually reinforcing.

\section{A Human Right to An Environment - Myth or Fact}

Scholars such as Merrills argue that increasingly a broad 'right to environment' has been added to the list of traditional human rights. Despite the lack of state support for establishing such a right at the Stockholm Conference and an avoidance of 'rights language' in the Rio Declaration which instead calls for the participation of the public in environmental matters on 
the grounds of 'efficiency' (Principle 10), a landmark development has been seen in the 1998 Convention on the Access to Information, Public Participation and Access to Justice in Environmental Matters (Aarhus Convention) which is the first environmental treaty to incorporate and strengthen the language of Principle 1 of the Stockholm Declaration which focused on an instrumental manner of giving content to environmental rights by identifying those rights that could be considered a prerequisite to effective environmental protection, namely, the right to information, participation and remedies.

\subsection{Regional Svstems}

Moreover, there have been several developments which illustrate that a right to environment might be said to have been established particularly in the regional context, namely through the 1988 Protocol of San Salvador - Article 11 (1) which states 'a right to live in a healthy environment and to have access to public services; 1981 African Charter on Human and People's Rights - Article 24 which states a 'right to a generally satisfactory environment'; the Convention for the Protection of Human Rights and Fundamental Freedoms, Rome, 1950, European Treaty Series No 5; the African Charter - Communication No 155/96 (Ogoni Case) The Social and Economic Rights Action Center and the Center for Economic and Social Rights v Nigeria; the African Commission on Human and People's Rights, $30^{\text {th }}$ Ordinary Session, October 2001. These then can be described as examples of 'use(ing) the language of human rights to promote or consolidate certain social values.'

Regional human rights bodies in Europe, the Americas and Africa have all examined cases alleging violations of the right to life due to environmental harm. Apart from receiving and examining individual complaints, the Inter-American Commission on Human Rights devoted particular attention to environmental rights in reports to Ecuador (1997) and Brazil (1997). The Commission also upheld the procedural dimension of environmental protection through human rights. The cases submitted in the African system invoked the right to health (article 16) rather than the right to environment contained in the same document. More recently, applicants successfully alleged a violation of the right to environment by Nigeria.

\subsection{International Conventions}

Further, an examination of recent international conventions in the field of environmental law signals the crystallizing of such a human rights to an environment. The Preamble of the Aarhus Convention expressly states that 'every person has the right to live in an environment adequate to his health and well-being...'

The following paragraph adds that to be able to assert this right and observe the duty, citizens must have access to information, be entitled to participate in decision-making and have access to justice in environmental matters. Informational rights are widely found in environmental treaties, in both weak and strong versions. Some examples are The Framework Convention on Climate Change (article 6); The Convention on Biological Diversity similarly does not oblige state parties to provide information, but article 14 provides that each contracting party 'as far as possible and as appropriate' shall introduce 'appropriate' Environmental Impact Assessment procedures and 'where appropriate allow for public participation in such procedures.'

Broader guarantees of public information are found in international instruments including the 1992 Helsinki Convention on the Protection and Use of Transboundary Watercourses and International Lakes (article 16); the 1992 Espoo Convention on 
Environmental Impact Assessment in a Transboundary Context (Article 3 (8)) and the 1992 Paris Convention on the North-East Atlantic (article 9).

\subsection{International Organizations}

International organizations have begun to play a critical role in recognizing the relationship between human rights and the environment as is reflected by non-binding declarations of a right to environmental information such as the World Health Organization's European Charter on Environment and Health, The Bangkok Declaration (1990) and the Arab Declaration on Environment and Development and Future Perspectives of September 1991. Further, United Nations human rights texts generally contain a right to freedom of information or a corresponding state duty to inform - Universal Declaration of Human Rights (article 19); the International Convention on Civil and Political Rrights (article 19 (2).

Additionally, the United Nations has on several occasions recommended measures in human rights protection which have had implications for environmental protection. Some noteworthy examples: The UN Human Rights Committee has indicated that state obligation to protect the right to life can require positive measures designed to reduce infant mortality and protect against malnutrition and epidemics implicating environmental protection. (UN ECOSOC General Comment 14, 2000). On November 8, 2000, the Committee on ESCR issued General Comment No 14 on 'Substantive Issues Arising in the implementation of the ICESCR Article 12 - the Committee states in para 4 that 'the right to health embraces a wide range of socio-economic factors that promote conditions in which people can lead a healthy life, and extends to the underlying determinants of health, such as .... healthy environment.'

\subsection{The Public}

The major role played by the public in environmental protection is participation in decisionmaking, especially in environmental impact or other permitting procedures. Public participation is based on the right of those who may be affected to have a say in the determination of their environmental future. It is noteworthy that this is not restricted to residents but includes foreign citizens as well. Most recent multilateral and many bilateral agreements contain this - for example, the The Framework Convention on Climate Change (Article 4 (1) (i); The Convention on Biological Diversity (Article 14 (1) (a); regionally the Espoo Convention on Environmental Impact Assessment in a Transboundary Context. The right to public participation is widely expressed in human rights instruments as part of democratic governance and the rule of law: Article 21 of the UDHR, American Declaration on the Rights and Duties of Man (Article 20) and the African Charter (Article 13) and the ICCPR (Article 25).

\section{A Human Right to an Enrivonment - Problem or Solution?}

The concept of a right to a healthy and safe environment has generated debate and contradicting developments. Not every social problem must result in a human right. Writers such as Shelton argue that the recognition that human survival depends upon a safe and healthy environment places the claim of a right to environment fully on the human rights agenda. This has been underscored by the recent development at the United Nations' General Assembly where the access to clean water and sanitation was declared a human right, with overwhelming support in favour of the resolution, where 122 nations voted in favour, zero 
voted against and 41 abstained. This landmark development in July of 2010 takes the debate on a human right to an environment one step closer to fruition, where the establishment of the inextricable linkage between the right to life and a clean environment was reflected in the interventions made by Permanent Representative of the Plurinational State of Bolivia, Ambassador Pablo Solon, New York when he remarked that 'safe and clean drinking water and sanitation is a "human right that is essential for the full enjoyment of life and all human rights," going further to say that ' drinking water and sanitation are not only elements or principal components of other rights such as "the right to an adequate standard of living." The right to drinking water and sanitation are independent rights that should be recognized as such. It is not sufficient to urge States to comply with their human rights obligations relative to access to drinking water and sanitation. Instead, it is necessary to call on states to promote and protect the human right to drinking water and sanitation.' Moreover, this could embrace elements of nature protection and ecological balance, areas not covered in human rights law because of its anthropocentric focus.

As a result it is argued that this could prove to be problematic in that it would begin to refashion the entire human rights framework. On this argument then it is argued that the right to an environment should not be included as a human right.

There have been several arguments advanced for the establishment of a substantive right to the environment. Successfully placing personal entitlements within the category of individual human rights preserves them from the ordinary political process and limits the political will of a democratic majority and a dictatorial minority. This is useful particularly given the high short-term costs of environmental protection measures unfavourable to politicians.

However, writers such as Merrills argue that incorporation of environmental rights into national constitutions and international treaties does not guarantee that the holder of that right will always be successful when in conflict with other rights. Nevertheless, he asserts that this will ensure that environmental rights will always be taken into account and also that good reasons will be needed for denying them. Encapsulating values as rights are instrumental in ensuring that they are to be taken seriously. Designating an entitlement as a 'human' right is even better given the status of this class of rights in legal and moral discourse.

Furthermore, given the close relationship between law and morals in the area of environmental protection, it is difficult to argue for the legal status of environmental rights given its consistency with the rationale for human rights. The rights of an individual is an issue when what is at stake is bound up with life, property and control of one's affairs.

Therefore, there is nothing in the concept of environmental rights that appears to be incompatible with this thinking. Formulating the right as collective rather than individual as in the African Charter more accurately captures its essence as it is vital to the existence or survival of the beneficiaries where the right could be an economic, social or cultural right, involving claims on resources of a wider community rather than simply a protection from interference. 


\section{Carving out a Human Right to the Environment}

The definition of a right to environment would have to include substantive environmental standards to restrict harmful air pollution and other types of emissions. Establishing the content of a right through reference to independent and variable standards is often used in environmental rights particularly with regard to economic entitlements and needs not be a barrier to a specific environmental quality. An approach similar to the ones adopted in other human rights treaties can be utilized to give meaning to the right to environment. Flexible obligations cognizant of the dynamic character of the right that is subject to variability in implementation in response to different threats over time need not undermine the concept of a right.

Over one hundred constitutions throughout the world guarantee a right to a clean an healthy environment and impose corresponding duties on a state. Over half of these constitutions and nearly all of which were adopted since 1992 explicitly recognize this. Yet another noteworthy trend is that these constitutionally guaranteed rights are being enforced by courts in India, South Africa, Argentina, Columbia and Costa Rica. Most international human rights instruments were drafted prior to the emergence of environmental law as a common concern and hence do not mention the environment. The United Nations Convention on the Rights of the Child is unique in its statements for the provision of clean drinking water and the dangers of pollution.

At a regional level, the African Charter on Human and People's Rights was the first human rights instrument to contain an explicit guarantee of environmental quality (article 24). The case of Ogoniland, Nigeria is considered landmark also for the African Commission's articulation of duties of governments in Africa to monitor and control the activities of multinational corporations. The Commission accorded meaningful content to the right to environment by imposing the requirement on states to adopt various techniques for environmental protection. The result offers a blueprint for merging environmental protection, economic development and guarantees of human rights.

At the global level, several non-binding instruments include references to 'environmental rights' or 'right to an environment of a special quality.' The United Nations Sub-Commission on Prevention of Discrimination and Protection of Minorities; the Special Rapporteur annexed a set of Draft Principles on Human Rights and the Environment to her final report in 1994 of the study of the environment and its relationship with human rights. More recently, in 2001, the UN Human Rights Commission affirmed that 'a democratic and equitable international order requires...the realization of ...(t)he right of every person and all peoples to a healthy environment.'

Most recently, in July 2010, the far-reaching importance of the right of access to clean water and sanitation as being the bedrock upon which all human rights rest was reflected in the declaration of a human right to access clean water and sanitation. This development, undoubtedly, makes the debate of those advocating for a human right to an environment much stronger. The particular connection drawn in support of the declaration, which was a result of extensive campaigning by many civil society organisations, was that between human health on the one hand, and water and sanitation on the other: The text of the resolution expresses deep concern that an estimated 884 million people lack access to safe drinking water and a total of more than 2.6 billion people do not have access to basic sanitation. Studies also indicate about 1.5 million children under the age of five die each year and 443 million school days are lost because of water- and sanitation-related diseases; Every year, 3 and a half 
million people die of waterborne illness; the text of the convention highlights that the situation of lack of sanitation is far worse, for it affects 2.6 billion people, or 40 per cent of the global population.

\section{Challenges}

However, writers such as Merrills points out the attendant dangers in recognizing a human right to the environment. He contends that it can threaten social harmony and in some cases social welfare as it will create conflict when right holders come into confrontation with other right-holders and will also generate a tension between rights as a basis for action and other moral consideration.Writers like Alston discuss the need for 'quality control' when establishing 'new' human rights. He argues that this is not to suggest that environmental rights are unworthy of protection but rather that they are adequately protected already and will serve relatively little use in the decision. Another question that has been raised - is it useful or indeed sensible to create yet another conceptual boundary? Would it not be more meaningful to place these issues in their appropriate context rather than to invent a new and somewhat amorphous right altogether?

Defining right-holders and duty-bearers are also controversial issues that they need to be resolved as they are crucial to the right concerned. Writers like Crawford discusses how group rights are controversial as they have to be construed conceptually for particular purposes as they lack an intrinsic identity. Another controversial right-holder is 'future generations.' This issue has been raised but not resolved in EHP v Canada. Merrills suggests that this may be thought of as a special type of collective right than as an indefinite number of individual rights thereby distinguishing it from the right of unborn foetuses.

Yet another issue to be considered is whether animals should be another class of rightholders on the grounds of being affected by our treatment of the environment and unlike future generations are part of the here and now. Writers like Lomasky contend that animals fail to qualify for the moral community resting on autonomy and self-realization as they are not generations of personal value. The case for inanimate objects like mountains, rivers, trees or the earth itself as having rights is less convincing.. Such a wholesale approach detracts from anthropocentricism which can be a drawback of a human-rights approach to environmental protection. One of the continuing difficulties conceptually is that 'environmental' rights does not include the 'natural' or wildlife elements of the environment except perhaps through an NGO who has been granted locus standi to act on behalf of such an interest. As these are limited to situations where harm to the environment does not directly have immediate consequences for human welfare there is still no actual human right to ensure protection of the natural environment per se.

Environmental protection cannot perhaps be wholly incorporated into the human rights agenda without deforming the concept of human rights and distorting its programme. Further, certain human rights are not directly affected by environmental considerations, for instance, the right to a name. The debate, therefore, is likely to continue over whether recognition of flora and fauna nor ecological balance furthers environmental protection or will serve to further the anthropocentric, utilitarian view that the world's resources exist solely to further human well-being. If the right to the environment becomes a part of the human rights catalogue, the challenge of balancing it with other human rights remain. 
That said, the words of the Permanent Representative of the Plurinational State of Bolivia, Ambassador Pablo Solon, New York in his statement leading up to the declaration of a human right to access clean drinking water and sanitation in 2010 ring deep when he makes the case for the human right to access clean drinking water and sanitation on the grounds of human dignity: "Sanitation, more than many other human rights issue, evokes the concept of human dignity; consider the vulnerability and shame that so many people experience every day when, again, they are forced to defecate in the open, in a bucket or a plastic bag. It is the indignity of this situation that causes the embarrassment."

In the context of the compelling arguments forwarded in the above statement that has been coupled with the overwhelming support of the international community that led to the adoption of a declaration in favour of a human right to access clean drinking water and sanitation, the case against the establishment of a human right to an environment argued in light of the challenges list above are harder to sustain, now more than ever before.

\section{Conclusion}

A potential factor that could bridge human rights and environmental protection, is human health, being a primary objective of both areas of regulation. Thus, the goal of human health provides the basis for reinforcing both areas of law. Scholars such as Christopher D. Stone go one step further in identifying the ethical quandaries implicating the efforts to mend the global environment: first, issues of human obligation to the non-human environment; second, issues of ethics among states with respect to the environment; and third, issues of ethics among generations with respect to the environment.

Though it has been consistently contended that there is a human rights to a healthy and decent environment and there are many international instruments stating it, 'environmental' rights per se have not yet been expressly included in an binding global, as opposed to regional/bilateral, environmental or human rights treaty. Further, the growing body of cases asserting 'environmental' rights within various global and regional human rights treaty mechanisms, have been claimed in the absence of, rather than due to, relevant treaty provisions for these rights. Moreover, even when such a right is expressly incorporated the issue of litigation and enforcement remain.

As illustrated by the ECTHR the trend in this field has been the recognition of procedural rights like protecting the exercise of a relevant human right from environmental interference or other type of polluting activity rather than a recognition of a substantive right to a clean or healthy environment per se.

While the ECTHR's activist approach is not to be dismissed but rather saluted, the 'twostep jurisprudential process' of the court has allowed the respondent state a wide margin of appreciation when balancing rights of the individual and the wider community interests. This deference can perhaps be attributed to 'a general reluctance to substitute its own view for that of democratically elected or at least representative government.' This makes it difficult for the applicant who has to satisfy a high standard of proof. Now governments have to show that they have factored competing interests when they pass regulation affecting the environment. Hence, this 'due diligence' - type obligation 'appears to go further than the requirement laid down in the Hatton case'. 
Ultimately, the critical issue is that if the right to the environment becomes a part of the human rights catalogue, the challenge of balancing it with other human rights remains. On the one hand, since the future of humanity depends on maintaining a habitable planet effective measures to protect the environment are crucial to any project for advancing human rights. On the other hand, human rights law already protects interests such as life and home, allowing claims at the regional and international levels, thereby enabling environmental matters to be petitioned at both regional and internationa levels, by those affected. Hence, it has become evident that enforcing established human rights is already contributing something to environmental protection.

In the final analysis, the fact that the dignity of human life and living is increasingly being attributed to a healthy and clean environment makes it difficult to counter the need for a susbstantive human right to an environment - hence, it is the approach that is best out of the four formulations of the relationship between human rights and the environment presented at the outset of this paper, as it will both establish the right, not leaving room for detractors to shy away from what it entails, and more importantly, ensuring that it is taken seriously and for the purpose for which it is intended. 